\title{
Primary School Students' Learning Anxiety during the COVID- 19 Pandemic
}

\section{Sri Wulan Anggraeni ${ }^{*}$, Yayan Alpian ${ }^{2}$, Siti Kodariah ${ }^{3}$}

1,2,3 Program Studi Pendidikan Guru Sekolah Dasar, Universitas Buana Perjuangan Karawang, Indonesia

\begin{tabular}{l} 
A R T I C L E I N F O \\
\hline Article history: \\
25 December 2020 \\
Received in revised form \\
01 January 2021 \\
Accepted 25 January \\
2021 \\
Available online 03 \\
Pebruari 2021 \\
Kata Kunci: \\
Kecemasan Belajar, \\
Siswa Sekolah Dasar \\
Keywords: \\
Learning Anxiety, \\
Elementary School \\
Students
\end{tabular}

\begin{abstract}
A B S T R A K
Penelitian ini bertujuan untuk mengetahui bagaimana kecemasan belajar peserta didik sekolah dasar di masa COVID-19, Metode Penelitian ini menggunakan pendekatan deskriptif kualitatif dengan teknik pengumpulan data observasi, wawancara, dan angket/kuesioner. Data dianalisis melalui tahapan reduksi data, penyajian data, dan penarikan kesimpulan. Subjek dalam penelitian ini adalah siswa sekolah dasar, guru, dan peran serta orangtua siswa. Hasil dari penelitian ini menunjukkan bahwa tingkat kecemasan belajar siswa sekolah dasar pada masa pandemi COVID-19 tidak menunjukan tingkat kecemasan yang tinggi atau masih dibatas wajar dan masih dinilai ringan, tidak menimbulkan kecemasan yang berlebih. Selain itu peran serta orangtua dalam mendampingi dan membimbing siswa belajar di rumah terbilang efektif dapat mengatasi kecemasan belajar siswa. Berbagai upaya dilakukan untuk mengatasi kecemasan belajar siswa pada masa pandemi COVID-19. Temuan ini menyimpulkan bahwa kecemasan yang dialami siswa sekolah dasar masih batas normal.
\end{abstract}

\begin{abstract}
A B S T R A C T
This study aims to determine how elementary school students' learning anxiety during the COVID-19 period. This research method uses a qualitative descriptive approach with observation data collection techniques, interviews, and questionnaires. The data were analyzed through the stages of data reduction, data presentation, and conclusion drawing. The subjects in this study were elementary school students, teachers, and the participation of students' parents. The results of this study indicate that the level of learning anxiety of elementary school students during the COVID-19 pandemic did not show a high level of anxiety or was still limited and still considered light, did not cause excessive anxiety. Besides, the role of parents in accompanying and guiding students to study at home is quite effective in overcoming student learning anxiety. Various efforts were made to overcome student learning anxiety during the COVID-1 pandemic. These findings concluded that the anxiety experienced by elementary school students was still within normal limits.
\end{abstract}

\section{Introduction}

COVID-19 (Corona Virus Disease 2019) is a highly contagious disease with a long incubation period caused by Sars-Cov-2 (Severe Acute Respiratory Syndrome Coronavirus 2)(Dewi, 2020; Goldschmidt, 2020; Zhang \& Ma, 2020). The number of patients is increasing every day. This has a psychological impact on the public's fear of the coronavirus. This virus can threaten a person's physical health, and also affect people's mental health, especially in terms of emotions and cognition, as indicated by the Behavioral Immune System (BIS) theory, people tend to develop negative emotions, for example, reluctance, anxiety, and negative cognitive judgments to self-protection (Goldschmidt, 2020; Jr, J.Shook, \& A.McDaniel, 2013; Kuhfeld et al., 2020). Facing the potential threat of disease, people tend to develop avoidant behaviors, for example, avoiding contact with people who have pneumonia-like symptoms and strictly adhering to social norms (Schaller, R, Murray, \& Bangerter, 2015).

The Indonesian government has issued several policies aimed at reducing the spread of the coronavirus, including social and physical separation before the enactment of the PSBB (large-scale social restrictions) in several areas. The policies in place to combat the spread of COVID-19 have an impact on various fields in the world, especially education (Bao, 2020; Fitriyani, Fauzi, \& Sari, 2020; Herliandry et al., 2020). Almost all education around the world experienced disruption in face-to-face teaching during the 
2019-2020 school year due to the COVID-19 pandemic. As a result of the COVID-19 pandemic, the government issued a distance learning policy, but it is still unclear how effective distance learning will be, given that most students and teachers have little experience with online learning and many parts of the country have gaps in access to technology. One of them is the impact of the COVID-19 pandemic on education in Indonesia.

The condition of the world of education in Indonesia is currently experiencing a phase of anxiety for students and parents in following the learning process, due to conditions that have not been optimal due to the impact of the COVID-19 pandemic (Corona Virus diseases-19) that has hit Indonesia. The government issued a policy for all students studying at home, to reduce social activities outside the home. During extended school closings, many working parents struggled to educate and care for their children. This is a unique challenge in the world of education as this pandemic impacts broader shocks to society accompanied by a major economic downturn, job losses, widespread protests over financial injustice, and the real health threat of COVID-19 (Fitriyani et al., 2020; Harris \& Larsen, 2019; Herliandry et al., 2020; Kuhfeld et al., 2020).

The public health problems posed by the COVID-19 outbreak have prompted online learning at the same time. Teachers and educators must undergo a large-scale migration that is ongoing from conventional face-to-face education to online education or distance education as a basic element of teaching, even though educators and learners are in multiple locations, online learning is effective for carrying out learning (Dewi, 2017; Irawan et al., 2015; Susanti, 2019).

But in reality, online learning is not running effectively. Based on the results of observations that occurred at SDN Sukamakmur 1, Karawang Regency, there were many obstacles experienced by teachers and students. The limited technological capabilities of teachers and parents of students are an obstacle in online learning. There are many learning platforms available, but the teacher only informs the material through the WhatsApp platform and the teacher sends more assignments than material. It was at this time that students' anxiety in learning began to emerge because not all parents were sensitive to the material and assignments that the teacher sent to each parent's cellphone so that online learning did not go as it should. Teachers and students have limited technology in the distance learning process, this can make students anxious in learning, become discouraged, and indifferent to the material being taught, so that it can affect learning achievement (Syamsuar \& Reflianto, 2018).

During studying at home, students began to get bored and there was a tendency for students to be at home just playing as if neglecting their duties as students who had to continue studying at home. They are still unable to adapt to the changes in learning that are happening at this time and the low awareness of students in learning so that they do not learn and ignore the assignments given by the teacher.

The coronavirus pandemic also affects the level of learning anxiety of students, namely being faced with multiple anxieties, including the COVID-19 outbreak and school assignments. The COVID-19 pandemic has helped change the world order of education, starting from the learning process, learning methods, regulations, to the goals of education itself. This metamorphosis requires adjustment so that teaching and learning activities are always effective. In the learning process, for example, the teacher is no longer obliged to meet face to face with students because it can be done using distance education methods.

Many parties are restless because of changes in government policies that change the learning process from studying at school to being at home. This policy change requires the government and related institutions to provide an alternative learning process for students who cannot follow the learning process. The COVID-19 outbreak has claimed many victims, ranging from education at the level of Elementary School / Madrasah Ibtidaiyah, Junior High School / Madrasah Tsanawiyah, and Senior High School/ Madrasah Aliyah, to higher education. Increasingly day by day, the spread of the virus is spreading to several areas in the Indonesian archipelago.

Anxiety is a subjective feeling of disturbing mental tension like a normal reaction to an inability to cope with it (Anita, 2014; Hayat, 2017). Unexplained anxiety is experienced by everyone when experiencing a condition or emotional state that is not good and is a blurry experience followed by feelings of confusion and undirected. This anxiety can occur anytime, anywhere, it will happen and always accompanies the human heart. This anxiety can be a source of encouragement to act towards progress and happiness in life when conditions are within normal limits (normal anxiety), but anxiety that exceeds normal limits (neurotic anxiety) or is high will disturb self-stability and life imbalance occurs (Hayat, 2017; Inikah, 2015; Purnomo \& Suci, 2016).

Anxiety is an emotional condition with the emergence of unpleasant feelings in an individual, accompanied by feelings of uncertainty and the cause is not known or something that is not clear or vague (Annisa \& Ifdil, 2016; Inikah, 2015; Purnomo \& Suci, 2016; Yanti, Erlamsyah, \& Zikra, 2013). Anxiety can be defined as an unpleasant feeling, which is characterized by terms such as worry, concern, and fear 
which are sometimes experienced to varying degrees, moderate levels of anxiety usually help people learn, while high levels of anxiety make it difficult to learn.

The emergence of anxiety disorders due to threatening conditions, which is a normal reaction to stress (Rita L Atkinson, 2018). People with anxiety disorders are more likely to display feelings of panic and fear. During a panic attack, the person feels confident that something scary is going to happen. This feeling is usually accompanied by certain symptoms such as palpitations, shortness of breath, sweating, muscle tremors, fainting, and nausea. Usually, these symptoms result from stimulation of the sympathetic branch of the autonomic nervous system and are the reactions that other people experience when they are very frightened. During high panic attacks, it is usually caused by a person being afraid of death.

The anxiety experienced by students at school can be in the form of realistic, neurotic, or moral anxiety. Sutejo revealed that anxiety is a psychological process that is not visible to the surface, so to find out a student's anxiety, careful study is needed, trying to identify symptoms or symptoms, and the factors that underlie and influence them. However, it should be noted that the symptoms of anxiety that can be observed on the surface are only a small part of the real problem (Anita, 2014; Inikah, 2015; Sutejo, 2018; Yanti et al., 2013). Behind the problems and complaints of students about the impact of COVID-19 is learning anxiety. The condition due to the COVID-19 pandemic raises student learning anxiety which has an impact on student learning outcomes, this is due to a situation that leads to an unpleasant heart condition, feelings of restlessness, restlessness, anxiety due to these problems. Among them, students who have not mastered technology will feel burdened by the online learning system. Because in this era of increasingly rapid technological disruption, teachers and students must have mastery in the field of learning technology.

Mastery of learning technology for students and teachers which are very varied is a challenge in itself. Through the Work From Home (WFH) policy, it can pressure them to have capabilities in the field of digital learning technology as their need. Changes that are fast and not accompanied by good adaptability will cause fear and will not succeed in achieving what you want, such as fear, and this is known as anxiety. The period of the COVID-19 pandemic forced all learning processes to be carried out online as a solution to the continuing education process in difficult times like this. The difficulties of online learning are not only experienced by students in elementary schools, but students also experience almost the same difficulties. Online learning can have positive and negative impacts for students, the positive impact on students can easily get material and learn to assess their learning wherever they are, whether at home or in other public places, while the negative impact is that many students are not wise in online learning systems, and spending time learning with things that are arguably less meaningful, and can be detrimental to themselves (E. U. Dewi, 2020; Djuniadi, 2012; Sukardi \& Rozi, 2019).

The impact of COVID-19, which causes online learning, has an impact on elementary school students, the problem is even more complex than the problem for students. The impact of learning carried out at home is not only felt by students but also on the parents of students. There is a lot that parents and students feel during online learning. Judging from the positive impact, it is that students spend a lot of time understanding the material and have emotional closeness with their parents. However, the negative impact is even more complex, namely, students find it difficult to get material apart from the teacher. On average, parents of students are still unfamiliar with finding sources on the internet and find it difficult to use other learning applications. Parents of students are required to provide time to use their cellphones as their child's learning class. If parents cannot use learning applications, then parents feel burdened and eventually cause anxiety.

Learning at home, parents are required to maintain the rhythm of learning of students as befits learning in school. There are a schedule and series of lessons that the teacher continues to monitor through online media, while parents must ensure that everything goes well. Changes in learning methods require all groups to comply with all possible means so that the learning process can run properly, and the choice is to use technology as a means of the online learning process. The use of this technology is not without obstacles, some factors hinder the effectiveness of online learning, including low mastery of technology, limited facilities and infrastructure, internet networks, and costs (Andiarna \& Kusumawati, 2020; Purwadi, Hadi, \& Najwa, 2018; Yunitasari \& Hanifah, 2020).

The condition due to the COVID-19 pandemic raises student learning anxiety which has an impact on student learning achievement, this is due to feelings that refer to unpleasant moods such as feelings of panic, nervousness, worry caused by problems. Among them, it requires students to study at home, there is no face-to-face class, students who have not mastered technology will feel burdened by the online learning system, because of the limited technological abilities of parents and students. Besides, parents will find it difficult to maintain a child's learning rhythm like learning at school because the learning process at home is considered ineffective. This also has an impact on the level of anxiety of parents and students during the COVID-19 pandemic situation. 
Examining the above problems, the condition of education during the COVID-19 pandemic has caused anxiety for students. This anxiety will affect the psychological and decreased learning achievement of students. Therefore, the condition of students when learning activities must be in a comfortable and relaxed state, so that any material or information enters their mind properly so that students become calm and comfortable in learning. Thus, researchers are interested in conducting further research on the learning anxiety of elementary school students during the COVID-19 pandemic.

This research is supported by several relevant studies such as (1) research conducted by (Oktawirawan, 2020), who obtained the results of the research that the triggers for student anxiety during online learning included difficulty understanding the material, difficulty doing assignments, the availability and condition of the internet network, technical problems, and worries about the next assignment; (2) research conducted by (Fitriyani et al., 2020), who obtained the research results that there were 8 student learning motivations in online learning during the Covid-19 pandemic; (3) research conducted by (Andiarna \& Kusumawati, 2020), who obtained research results that online learning needs to be supported by facilities and infrastructure, readiness and skills of lecturers so that academic stress on students can be avoided.

The purpose of carrying out this research is to analyze how the learning anxiety of students at SDN Sukamakur I, Karawang Regency during the COVID-19 pandemic.

\section{Method}

The research method used is qualitative. According to Creswell, qualitative research is a type of research that explores and understands the meaning of many individuals or groups of people originating from social problems (Raditya \& I, 2019; Rahmasantika \& Prahmana, 2018). This type of qualitative research used is descriptive, which is to examine the problem of the impact of Covid 19 on students' learning anxiety.

The subjects in this study were 18 students of SDN Sukamakur I, Karawang Regency. Other subjects to support research data are teachers and the participation of students' parents.

Data collection techniques are methods that researchers can do or use to collect data. Data collection techniques used in this study were observation, interviews, and questionnaires. The first data collection is observation. This data collection technique is carried out by observing existing and occurring phenomena. The purpose of this observation technique is to observe learners' learning anxiety while studying at home during the COVID-19 pandemic. The observation guideline sheet for observing student anxiety can be seen in Table 1 .

Table 1. Guidance sheet for observing students' anxiety

\begin{tabular}{cll}
\hline Aspects Observed & & \multicolumn{1}{c}{ Description } \\
\hline Anxiety & a. & Students feel uneasy while studying. \\
& b. & Students have a high level of anxiety \\
Worries & a. & The panic feeling while studying \\
& b. & Feelings of panic when students can't solve a problem \\
Basic fear & a. Students feel anxious when facing problems \\
& b. Students feel afraid when they find new problems \\
Situation Awareness & a. & Be aware of something foreign to students \\
& b. & Beware of people around you who don't know \\
\hline
\end{tabular}

The second data collection interviews. This technique is used by researchers to extract data, information, and information frameworks from research subjects. The type of interview used is semistructured. This type of interview is included in the in-depth interview category, which in practice is freer than structured interviews. The purpose of semi-structured interviews is to find problems in a more open manner, where informants are asked for their opinions and ideas. The subjects interviewed in this study were students, teachers, and parents of students around the SDN Sukamakmur 1 school. The purpose of this interview was to collect data about students' learning anxiety during the COVID-19 pandemic. continue from the observation process so that the data obtained can be accounted for.

The third data collection is a questionnaire. This technique is used to obtain information from respondents in terms of their personality, or other things they are aware of. In this study, the authors used an open questionnaire where the answers were available, but the respondents could still write their answers if there were no available options. The targets that will be given a questionnaire are students of SDN Sukamakmur 1, and parents of students. This questionnaire technique was used to obtain data on 
respondents from grade V SDN Sukamakmur 1 about students' learning anxiety during the COVID-19 pandemic.

The fourth data collection is triangulation. This triangulation aims to collect data as well as test the credibility of the data, namely checking the credibility of the data with various data collection techniques and various data sources. Therefore, the researchers collected various data with the same source, namely those obtained from data collection of students, teachers, and parents of students of SDN Sukamakmur I, Karawang Regency, then data triangulation techniques were carried out as a step to test the validity of the data obtained by researchers.

The data analysis technique used in this research is to use an interactive model, whose elements include data reduction, data presentation, and conclusion/verification. The flow of data analysis techniques can be seen in Figure 1.

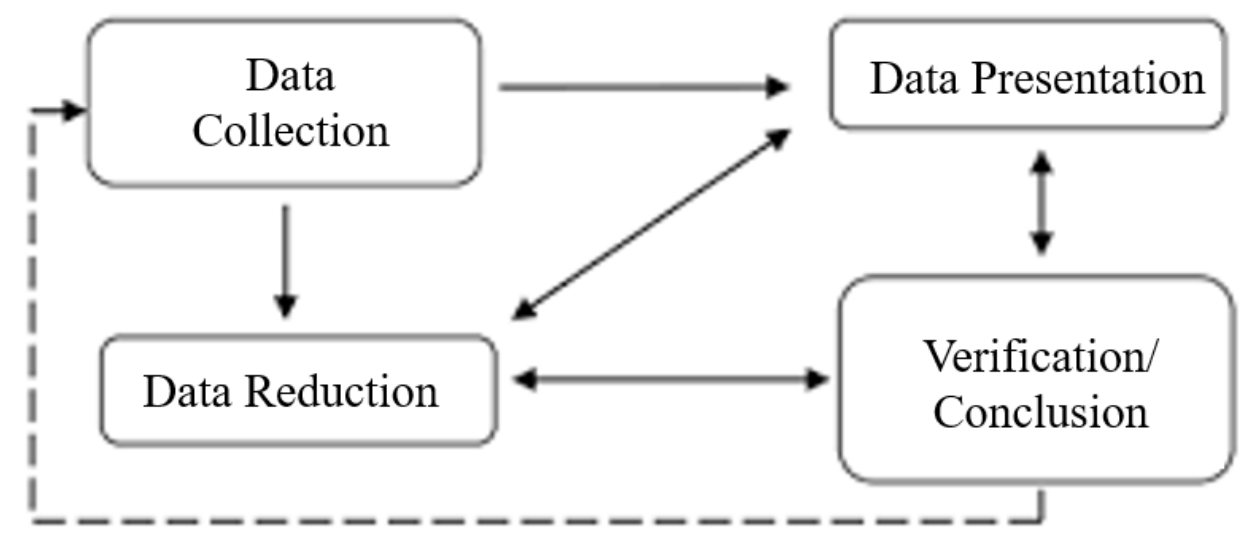

Figure 1. Components in data analysis (interactive model).

\section{Result and Discussion}

This section describes the findings regarding the analysis of learning anxiety among elementary school students during the COVID-19 pandemic, based on data obtained from interviews, observations, and documentation and strengthened by theoretical studies from various references.

The impact of the COVID-19 pandemic has an impact on the world of education, the central and local governments have decided on policies to close all educational institutions. This was done to minimize the spread of the COVID-19 virus. It is hoped that all educational institutions will not carry out their usual activities, this can reduce the spread of COVID-19.

Based on the results of observations, researchers observed students' daily learning activities at home. Researchers began to observe students' learning anxiety during the COVID-19 period, this can be seen from the results of observations that the researchers presented in Table 2.

Table 2. The observation results of students' learning anxiety

\begin{tabular}{|c|c|c|c|c|}
\hline No & Aspects Observed & Description & Yes & No \\
\hline \multirow[t]{3}{*}{1.} & Anxiety & a. Students feel uneasy while studying. & 8 & 10 \\
\hline & & b. Students have a high level of anxiety & 3 & 15 \\
\hline & & Presentase & $31 \%$ & $69 \%$ \\
\hline \multirow[t]{3}{*}{2.} & Worries & a. The panic feeling while studying & & 15 \\
\hline & & $\begin{array}{l}\text { b. Feelings of panic when students can't solve } \\
\text { a problem }\end{array}$ & $\begin{array}{c}3 \\
12\end{array}$ & 6 \\
\hline & & Presentase & $42 \%$ & $58 \%$ \\
\hline \multirow[t]{3}{*}{3.} & Basic fear & a. Students feel anxious when facing problems & & 3 \\
\hline & & $\begin{array}{l}\text { b. Students feel afraid when they find new } \\
\text { problems }\end{array}$ & 6 & 12 \\
\hline & & Presentase & $58 \%$ & $42 \%$ \\
\hline \multirow[t]{3}{*}{4.} & Situation & a. Be aware of something foreign to students & & 2 \\
\hline & Awareness & $\begin{array}{l}\text { b. Beware of people around you who don't } \\
\text { know }\end{array}$ & 15 & 3 \\
\hline & & Presentasi & $86 \%$ & $14 \%$ \\
\hline
\end{tabular}


Based on the data from observations made by researchers in learning activities of students during the COVID-19 period which have been carried out at home, the data can be seen from the aspect of anxiety, students tend not to have excessive anxiety, this is shown in the data only $31 \%$ said students restless, but the remaining $69 \%$ of the 18 students were said to be not anxious, meaning that the learning period during the COVID-19 period had no impact on the level of anxiety of students. This is inversely proportional to the many studies that prove that the COVID-19 pandemic can disrupt human mental health, one of which is anxiety (Cosic, Popovic, Arlija, \& zic, 2020; Kar, Yasir Arafat, Kabir, Sharma, \& Axena, 2020; Lee, 2020; Polizzi, Lynn, \& Perry, 2020; Roy et al., 2020). Along with the prevalence of media coverage about COVID-19, it can cause anxiety in humans. According to Hilgard, the emergence of anxiety is not focused on internal conflicts, but the way anxiety is associated with certain conditions through the learning process. This suggests that anxiety develops through learning to associate so that an initially neutral stimulus becomes anxiety due to conditioning based on association with an unpleasant stimulus (aversive stimulus) (Mu'arifah, 2005). However, what happened to the fifth-grade students of SDN Sukamakmur 1, they felt calm and happy to study at home and could even overcome their anxiety by playing games so that learning at home felt fun and not scary. Children are filling their spare time by playing games can be seen in Figure 2.

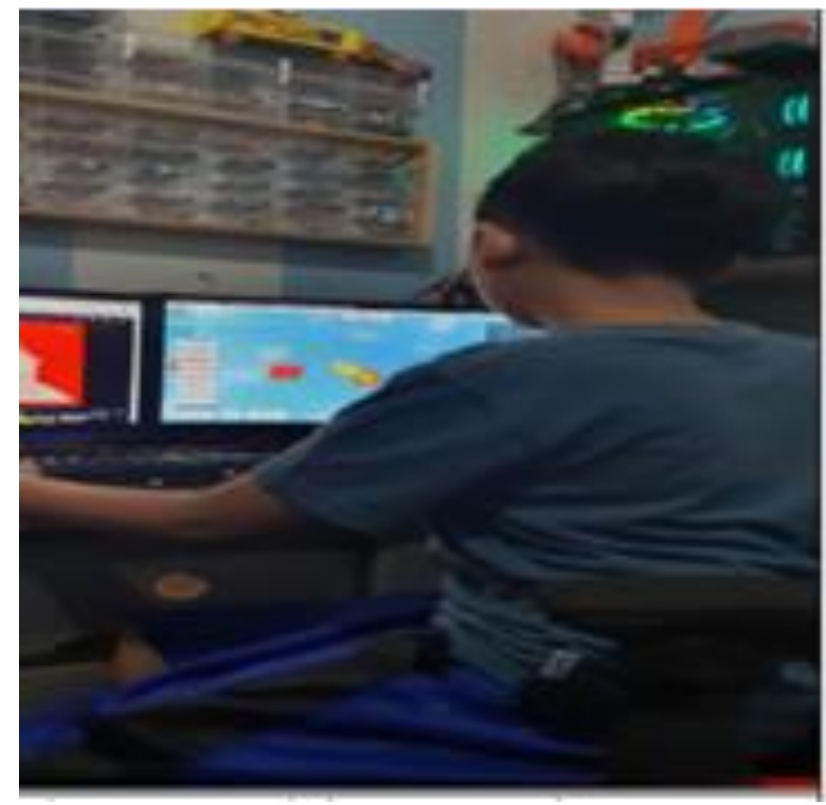

Figure 2. The child is filling his spare time by playing games

In the aspect of worrying while studying, dominant students do not show panic feelings when studying, namely, 15 students who do not panic when learning from 18 students. This data shows that students feel happy studying at home because they are freer and are not bound by time like at school. However, students feel worried about doing assignments from the teacher independently, because students feel less information and less understanding of the material when doing assignments so that which can cause concern for students if they are unable to do the assignments from the teacher. This can be seen in the panic feeling table when the students could not solve the problem which answered more worry, namely as many as 12 students out of 18 students. Even so, when viewed from the total percentage of worry, as many as $58 \%$ of the 18 students said they did not have an excessive level of worry, this can be seen from the feelings of students who can control worry when students learn at home. This is because the level of anxiety of elementary school students is still considered light, does not cause excessive anxiety. Besides, the role of parents in accompanying and guiding students to study at home is quite effective in overcoming students' learning anxiety. Activities carried out by students to relieve the pressure and anxiety they feel are listening to music, watching television or movies, eating, drinking tea, and exercising. Some students also choose to sleep to feel calmer and avoid excessive anxiety. Listening to music is considered to be able to make the atmosphere calmer and less boring for studying (Izzah, L. \& Humairoh, 2020; Septiani \& Hasanah, 2019). Activities such as watching television, playing games, and sleeping are indeed able to prevent students from feeling anxious. However, if done continuously it can also cause more serious problems because the causes of anxiety experienced are not handled (Mukminina 
\& Abidin, 2020). As is done with elementary school students who prefer to play games and watch TV while releasing boredom after online learning. Releasing boredom is very important to maintain the resistance of the students' bodies.

In the fundamental aspect of fear, in terms of students feeling anxious when facing problems, and students feeling afraid when they find new problems, it can be shown in the data that around $42 \%$ of students do not experience anxiety at all. This is shown by the students appearing to be doing routines as usual. Meanwhile, 58\% of the 18 students experienced a fundamental fear seen from how the students reacted when they found a problem and solved the problem. Fear of students occurs when students are given assignments from the teacher online, and students must collect within a predetermined time, especially if students have to use online learning platforms that they don't know before so that it can cause students to fear if they cannot participate in online learning. However, in addition to student fears, parents of students always accompany their children when learning online, so students can easily ask their parents for material that they do not understand. Students get supervision from their parents while studying at home can be seen in Figure 3.

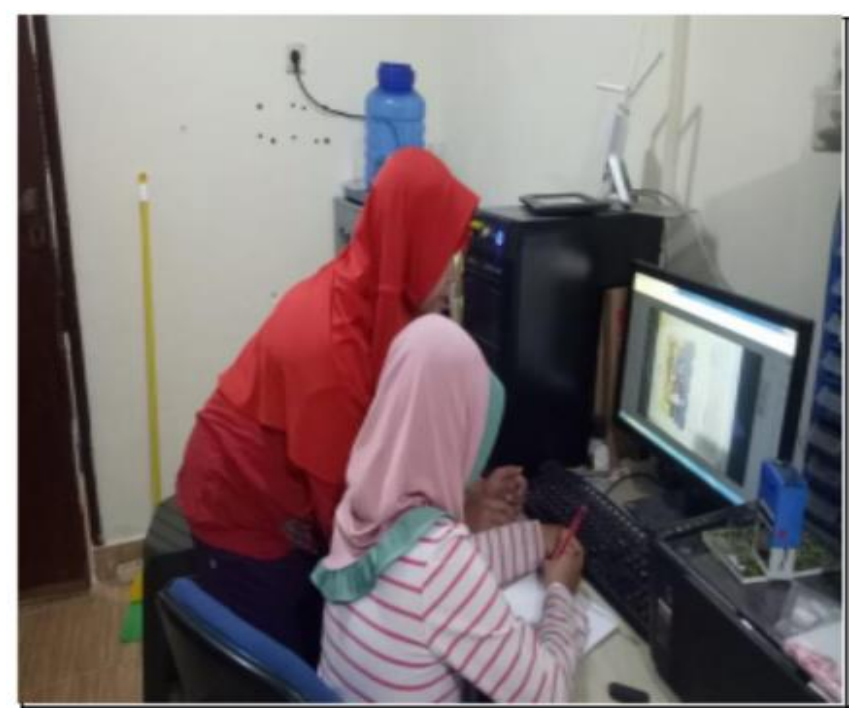

Figure 3. Students receive supervision from their parents while studying at home

Student panic arises if they cannot solve the problem, students experience this excessive worry when the parents of students work so that students do not get help from anyone in doing assignments from the teacher without direction from parents. This means that students feel unable to solve problems while learning, this can be seen from the level of difficulty of students when doing the assignments given by the teacher.

To overcome the anxiety experienced by students, the teacher conducts a home visit to the students' homes. Home visits are carried out by grouping students into several groups, so that every time the teacher teaches, they must visit the student study group according to the group. Each group consists of 10-15 students. Of course, teaching during the COVID-19 pandemic spent a lot of extra effort in teaching because the time spent by teachers was around 9 hours, which normally before the pandemic spent 5 hours teaching time. Within a day the teacher can teach 3 groups with a duration of two to three hours each for each group. Of course, this makes teachers have to be patient and rack their brains to provide optimal learning such as making learning videos, compiling modules, making media, and so on. The teacher conducting a home visit can be seen in Figure 4. 


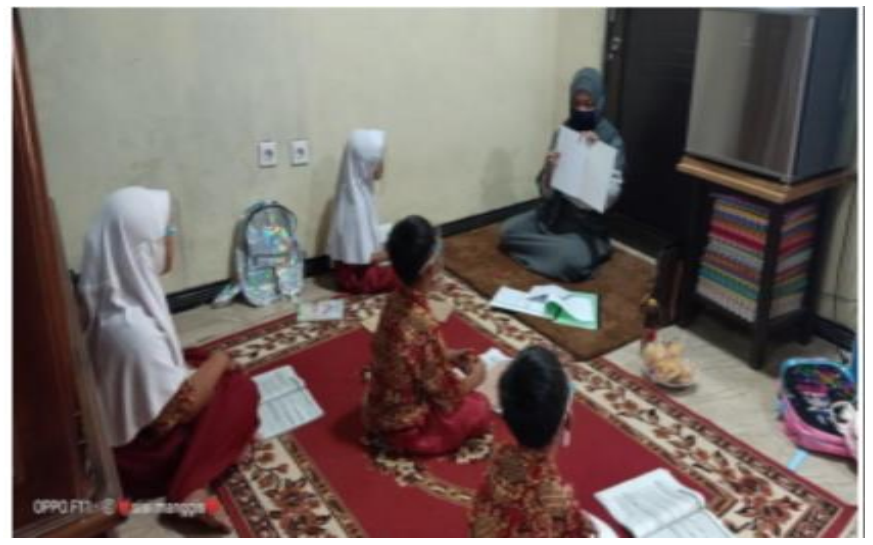

Figure 4. The teacher conducts a home visit

Even at home visits, the teacher reminded students to always be aware of the coronavirus, by implementing health protocols so that this appeal from the teacher, could increase students' awareness of the spread of the coronavirus. Judging from the aspect of vigilance towards the situation, in terms of being alert to something foreign to students, and being alert to people around who he does not know, it is shown in the data that around $86 \%$ of students are always alert. This means that students are always alert to something that has not been recognized. Meanwhile, $14 \%$ of the 18 students act naturally when they find something strange, even to people around whom they don't know. Students feel aware that the spread of the coronavirus can be transmitted through the touch of an infected person. Because of this awareness, students become alert when doing activities outside the home, especially when they come to visit home activities conducted by the teacher, students are aware that they always use masks, wash their hands, and keep their distance. And if there are students who forget to use a mask, then the student is better off going home again to take a mask than being scolded by their friends if they do not comply with health protocols.

\section{Conclusion}

Anxiety Learning of students in elementary schools during the COVID-19 pandemic shows that the level of anxiety is still reasonable. This is shown by students not feeling worried when they hear news about COVID-19, because students are always directed to adopt clean and healthy living habits while at home, and are always under the supervision of teachers and parents. Other activities carried out to reduce anxiety are sleeping, listening to music, watching television or playing games, eating and drinking, and sports that can make students avoid feeling anxious. Therefore, at the time of the COVID-19 pandemic, we should always be vigilant and always accompany children to continue learning from home. Doing positive things with the family to reduce the level of anxiety in children, parents are asked to remain patient in educating children at home. Always participate in children's activities while studying at home. Teachers as facilitators must also continue to monitor every child's learning and children's development while studying at home during the COVID-19 pandemic. Accepting the reality that exists is a solution for students to reduce anxiety in learning during the COVID-19 period. Make learning more fun and meaningful for students, so that students remain active and can focus on the following learning.

\section{References}

Andiarna, F., \& Kusumawati, E. (2020). Pengaruh Pembelajaran Daring terhadap Stres Akademik Mahasiswa Selama Pandemi Covid-19. Jurnal Psikologi Fakultas Psikologi UIN Sultan Syarif Kasim Riau, 16(2). https://doi.org/10.24014/jp.v16i2.10395.

Anita, I. W. (2014). Pengaruh Kecemasan Matematika (Mathematics Anxiety) Terhadap Kemampuan Koneksi Matematis Siswa Smp. InfinityJurnal Ilmiah Program Studi Matematika, 3(1), 125-138. https://doi.org/https://doi.org/10.22460/infinity.v3i1.p125-132.

Annisa, D. F., \& Ifdil, I. (2016). onsep Kecemasan (Anxiety) pada Lanjut Usia (Lansia). Konselor, 5(2), 9399.

Bao, W. (2020). COVID-19 and online teaching in higher education: A case study of Peking University. Human Behavior and Emerging Technologies, 2(2), 113-115. https://doi.org/https://doi.org/10.1002/hbe2.191. 
Cosic, K., Popovic, S., Arlija, M., \& zic, I. (2020). Impact of human disasters and Covid-19 pandemic on mental health: Potential of digital psychiatry. Psychiatria Danubina, 32(1), 25-31.

Dewi, E. U. (2020). Pengaruh Kecemasan Saat Pembelajaran Daring Masa Pandemi Covid-19 Terhadap Prestasi Belajar Mahasiswa Stikes William Surabaya. Jurnal Keperawatan, 9(1). https://doi.org/https://doi.org/10.47560/kep.v9i1.210.

Dewi, L. (2017). Designing Online Learning In Higher Education Institution: Case Study In Curriculum And Instruction Course At Indonesia University Of Education. Edutech, 16(2), 205-221. https://doi.org/10.17509/e.v16i2.7616.

Djuniadi, D. (2012). Fitur Motivasi Pembelajaran Online Dengan Pendekatan Pre-Defined Set. Jurnal Pendidikan Vokasi, 2(1), 41-52. https://doi.org/10.21831/jpv.v2i1.1015.

Fitriyani, Y., Fauzi, I., \& Sari, M. Z. (2020). Motivasi Belajar Mahasiswa Pada Pembelajaran Daring Selama Pandemik Covid-19. Jurnal Kependidikan: Jurnal Hasil Penelitian Dan Kajian Kepustakaan Di Bidang Pendidikan, Pengajaran Dan Pembelajaran, 6(2), 165-175. https://doi.org/10.23917/ppd.v7i1.10973.

Goldschmidt, K. (2020). The COVID-19 Pandemic: Technology use to Support the Wellbeing of Children. $\begin{array}{lllll}\text { Journal of Pediatric } & \text { Nursing, }\end{array}$ https://doi.org/https://doi.org/10.1016/j.pedn.2020.04.013.

Harris, D. N., \& Larsen, M. F. (2019). The Effects of the New Orleans Post-Katrina Market-Based School Reforms on Medium-Term Student Outcomes. Retrieved from https://educationresearchalliancenola.org/files/publications/Harris-Larsen-Reform-Effects2019-08-01.pdf.

Hayat, A. (2017). Kecemasan dan Metode Pengendaliannya. Khazanah: Jurnal Studi Islam Dan Humaniora, 12(1), 52-63.

Herliandry, L. D., Nurhasanah, Suban, M. E., \& Kuswanto, H. (2020). Pembelajaran Pada Masa Pandemi Covid-19. Jurnal Teknologi Pendidikan, 22(1), 65-70. https://doi.org/httos://doi.org/10.21009/jtp.v22i1.15286.

Inikah, S. (2015). Pengaruh Pola Asuh Orang Tua Dan Kecemasan Komunikasi Terhadap Kepribadian Peserta Didik. Jurnal Bimbingan Konseling Islam, 6(1), 19-40. https://doi.org/10.21043/kr.v6i1.1038.

Irawan, Y., Susanti, N., \& Triyanto, W. A. (2015). Analisa Dan Perancangan Sistem Pembelajaran Online (ELearning) Pada Smk Mambaul Falah Kudus. Simetris: Jurnal Teknik Mesin, Elektro Dan Ilmu Komputer, 6(2), 345-352. https://doi.org/10.24176/simet.v6i2.471.

Izzah, L., R., \& Humairoh, H. (2020). Pengaruh mendengarkan musik terhadap mood belajar pada mahasiswa manajemen dakwah UIN Suska Riau. Nathiqiyyah: Jurnal Psikologi Islam, 3(1), 1-6.

Jr, J. A. T., J.Shook, N., \& A.McDaniel, M. (2013). The behavioral immune system and social conservatism: a meta-analysis. Evolution and Human Behavior, 34(2), 99-108. https://doi.org/https://doi.org/10.1016/j.evolhumbehav.2012.10.003.

Kar, S. K., Yasir Arafat, S. M., Kabir, R., Sharma, P., \& Axena, S. K. (2020). Coping with Mental Health Challenges During COVID-19. In Coronavirus Disease 2019 (COVID-19) (pp. 199-213). https://doi.org/https://doi.org/10.1007/978-981-15-4814-7_16.

Kuhfeld, M., Soland, J., Tarasawa, B., Johnson, A., Ruzek, E., \& Liu, J. (2020). Projecting the Potential Impact of COVID-19 School Closures on Academic Achievement. Sagejournals, 49(8), 549-565. https://doi.org/10.3102/0013189X20965918.

Lee, J. (2020). Mental health effects of school closures during COVID-19. Retrieved January 14, 2020, from The Lancet Child and Adolescent Health website: https://doi.org/10.1016/S23524642(20)30109-7.

Mu'arifah, A. (2005). Hubungan Kecemasan dan Agresivitas. Humanitas : Indonesian Psychological Journal, 2(2), 102-111.

Mukminina, M., \& Abidin, Z. (2020). Coping Kecemasan Siswa SMA dalam Menghadapi Ujian Tulis Berbasis Komputer (UTBK) Tahun 2019. Jurnal Al-Azhar Indonesia Seri Humaniora, 5(3), 110-116.

Oktawirawan, D. H. (2020). Faktor Pemicu Kecemasan Siswa dalam Melakukan Pembelajaran Daring di Masa Pandemi Covid-19. Jurnal Ilmiah Universitas Batanghari Jambi (JIUBJ), 20(2), 541-544. https://doi.org/10.33087/jiubj.v20i2.932.

Polizzi, C., Lynn, S. J., \& Perry, A. (2020). Stress and coping in the time of COVID-19: Pathways to resilience 
and recovery. Clinical Neuropsychiatry, 17(2), 59-62.

Purnomo, Y. W., \& Suci, V. W. (2016). Hubungan Antara Konsepsi Penilaian dan Kecemasan Siswa Sekolah Dasar di Kelas Matematika. Beta Jurnal Tadris Matematika. https://doi.org/10.20414/betajtm.v9i1.5.

Purwadi, A., Hadi, M. S., \& Najwa, L. (2018). Pengembangan kelas daring dengan penerapan hybrid learning menggunakan chamilo pada matakuliah pendidikan kewarganegaraan. Edcomtech.

Rahmasantika, D., \& Prahmana, R. C. I. (2018). Analisis Kesalahan Siswa Pada Operasi Hitung Pecahan Berdasarkan Tingkat Kecerdasan Siswa. Journal of Honai Math, 1(2), 81-92. https://doi.org/10.30862/jhm.v1i2.1041.

Rita L Atkinson, dkk. (2018). Pengantar Psikologi (1st ed.). Jakarta: Binarupa Aksara.

Schaller, M., R, D., Murray, \& Bangerter, A. (2015). Implications of the behavioural immune system for social behaviour and human health in the modern world. Royal Society, 370(1669). https://doi.org/https://doi.org/10.1098/rstb.2014.0105.

Septiani, M. T., \& Hasanah, M. (2019). Media Audio Visual untuk Pembelajaran Musikalisasi Puisi. BASINDO: Jurnal Kajian Bahasa, Sastra Indonesia, Dan Pembelajarannya, 3(1), 31-37. https://doi.org/10.17977/um007v3i12019p031.

Sukardi, S., \& Rozi, F. (2019). Pengaruh Model Pembelajaran Online Dilengkapi Dengan Tutorial Terhadap Hasil Belajar. JIPI (Jurnal Ilmiah Penelitian Dan Pembelajaran Informatika), 04(02), 97-102. https://doi.org/10.29100/jipi.v4i2.1066.

Susanti, B. H. (2019). Penggunaan Media Online Dalam Proyek Pembuatan Bahan Ajar Berbasis Web Pada Mata Kuliah Zoologi Vertebrata. Edusains, 11(01), 22-28. https://doi.org/10.15408/es.v11i1.7728.

Sutejo. (2018). Keperawatan Jiwa, Konsep dan Praktik Asuhan Keperawatan Kesehatan Jiwa: Gangguan Jiwa dan Psikososial. Yogyakarta: Pustaka Baru Press.

Syamsuar, S., \& Reflianto, R. (2018). Pendidikan dan tantangan pembelajaran berbasis teknologi informasi di era revolusi industri 4.0. E-Tech: Jurnal Ilmiah Teknologi Pendidikan, 6(2). https://doi.org/10.24036/et.v2i2.101343.

Yanti, S., Erlamsyah, \& Zikra. (2013). Hubungan Antara Kecemasan Dalam Belajar dengan Motivasi Belajar Siswa. KONSELOR Jurnal Ilmiah Konseling, 2(1), 1-6. https://doi.org/https://doi.org/10.24036/02013211242-0-00.

Zhang, Y., \& Ma, Z. F. (2020). Impact of the COVID-19 pandemic on mental health and quality of life among local residents in Liaoning Province, China: A cross-sectional study. International Journal of Environmental Research and Public Health, 17(7), 1-12. 